\title{
The Consequences of PCBs and BPA Resulting from Terrorist Operations in Three Regions of Baghdad on Thyroid Function
}

\author{
Alaa H. Jawad ${ }^{1 *}$, Sara J. Kadhim ${ }^{1}$ and Zyad H. Jawad Al-Qaisi ${ }^{2}$ \\ ${ }^{1}$ Department of Chemistry, College of Science, Al-Nahrain University, Baghdad-Iraq. \\ ${ }^{2}$ Department of Chemistry, College of Science, University of Al-Mustansiriyah, Baghdad-Iraq. \\ * Corresponding author: alaaalqaisi74@yahoo.com
}

\begin{abstract}
Persistent organic pollutants polychlorinated biphenyls (PCBs) and bisphenol-A (BPA) are widely known of being toxicants. Exposure to a variety of dangerous toxic effects has been attached in all humans .in this paper the effect of terrorist operation on thyroid gland functions in a sample of Iraqi individual (AL-karradah and Abo-Gharib) comparison with Al-jadria rejoin as (control). The correlation between sera thyroid hormones thyroxine T4, triiodothyronine T3, Thyrotropin TSH and the levels of polychlorinated biphenyls (PCBs) and bisphenol-A (BPA) have been measured. 75 volunteers from three Iraqi areas were included in this study. Their ages ranged between (15-65) years. Our examination proposes an inverse relationship between BPA presentation and thyroid hormones. In this manner, increased persistent organic pollutants exposure might be a factor in the causes of hypothyroidism and thyroid gland function. The result of this study showed that the effect of persistent organic pollutants polychlorinated biphenyls (PCBs) and bisphenol-A (BPA) on thyroid hormones, and the effect of military and terrorist operations on the thyroid gland. In the end we concluded that persistent organic pollutants resulting from the explosions and terrorist operations in the area of (Al-karadah, Abo-Gharib) high compared with the control (Al-jadria) as the lowest percentage of pollution, this leads to many diseases on the health of the human body and also the effect of persistent organic pollutants on the thyroid gland and its negative effect on thyroid hormones and cause thyroid disease.

[DOI: $\underline{10.22401 / \mathrm{JNUS} .21 .3 .11]}$
\end{abstract}

Keywords: Persistent organic pollutants, Polychlorinated biphenyls (PCBs), Bisphenol-A (BPA), thyroid hormones, pollution, Baghdad area.

\section{Introduction}

Persistent organic pollutants (POPs) can be the reason of serious health effects with different signs depending on the nature and the amount of persistent organic pollutants consumed. Bioaccumulation means an increase in the degree of a chemical content in a living organism over time [1]. Studies of the effects of persistent organic pollutants contamination in any type of environmental pollution might adjust thyroid hormone (TH), increased thyroid gland length due to increased absorption of iodine, thyroid dysfunction, endocrine disorders and the impacts of persistent organic pollutants contamination on thyroid function. Naturally occurring, and temporal poisons that are concentrated in persistent organic pollutants pose a danger to enzymes and inhibit their function [2]. Polychlorinated biphenyls are persistent and toxic pollutants which have been widely dispersed into the environment [3]. Polychlorinated biphenyls are a group of industrial chemicals used as refrigerant or heat transfers agent in electric transformers. They have also been used in carbonless copy papers, capacitor, spills, dredge spoils, cutting oils, or as electrical insulators and also an inert ingredients in insecticides and PCBs may be found as intermediates and by products of other chemical [4].

Bisphenol $-\mathrm{A}$ is an endocrine hormone disrupting chemicals. A chemical used for commercial purposes, which is an additive in a multi-carbonate plastic as a growing production in thermal papers manufacturing and epoxy resins. Bisphenol-A is also found in preventing dental leakage, water bottles and bottles of children, paint, paper, adhesives, flames retardant materials, building materials, electronic components and beverage packaging [5]. Chemicals implicated in endocrine disruption include biocides, industrial compounds, surfactants, and plasticizers including bisphenol-A [6]. 
Air pollution studies and researches in Iraq are very limited particularly those on the air pollution from oil industries activities, some study had been carried out by Iraqi scientists and researchers on environmental air pollution in Iraqi governorates especially in some industrial areas [7]. PCBs each consists of an overall of 209 congener with changing grades of chlorination and various grades of bromination, respectively, also effects of personal congeners, toxic activities. While these compounds such as PCBs may came several of their toxicity from their structural correspondence to thyroxine also triiodothyronine [8]. BPA interferes with the thyroid system by binding to the thyroid hormone receptor. It causes a number of adverse health effects such as hypothyroid effect because it decreases the level of thyroid hormone [9]. Most realizations have focused on reproductive functions based on the estrogen-mimetic properties of this compound, leading to changes in thyroid hormones. However, guide has accumulated that BPA might have negative effects on other endocrine systems including thyroid function, suggests that BPA exposure might be associated with thyroid disruption characterized by a propose inverses correlation between BPA concentration with T4 concentrations [10]. BPA, which is utilized as a part of polycarbonate plastic products is widespread, epoxy pitches, manufacturing of thermal paper, and different items, has likewise been accounted for to apply consequences for the thyroid receptor in experimental thinks about, human investigations of BPA and thyroid hormones are missing, recommends in spite of the fact that a suggestive reverse relationship was seen between human serum BPA and thyrotropin (TSH) [11]. A previously reported a negative association between human serum BPA and human serum thyroxine with positive human serum thyroid antibodies [12]. A few studies have focused on whether BPA exerts its action through nuclear receptors such as thyroid receptors [13]. In the USA, 900 of the 1,300 most polluted sites-as indicated by Environmental Protection Agency (EPA) assessment - are military bases as well as testing sites that produced weapons, military related products in addition services.
These sites poisons to the environments and human health include training bases, abandoned disposal pits, chemical warfare and research laboratories. Poisons elements and compounds found there include organic solvents, pesticides, diesel fuel, heavy metals, rocket propellants, nuclear waste, machining oils, PCBs also toxic chemical compounds utilized in explosives [14]. This current examination's objective was to limit known variables of PCBs, BPA also thyroid hormones and effect of military and terrorist operations on the thyroid organ.

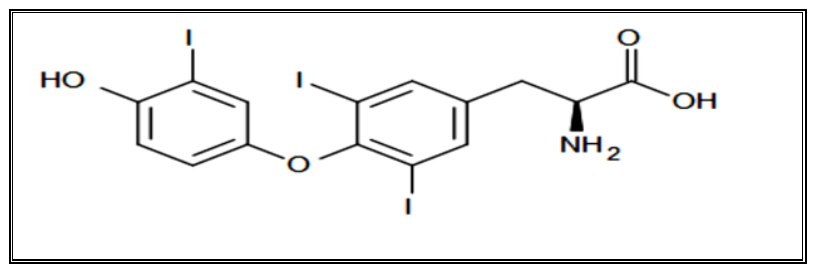

Fig.(1): Triiodothyronine (T3) structure [15].

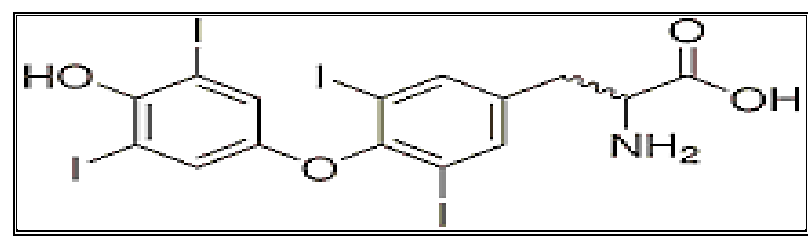

Fig.(2): Thyroxin (T4) structure [15].

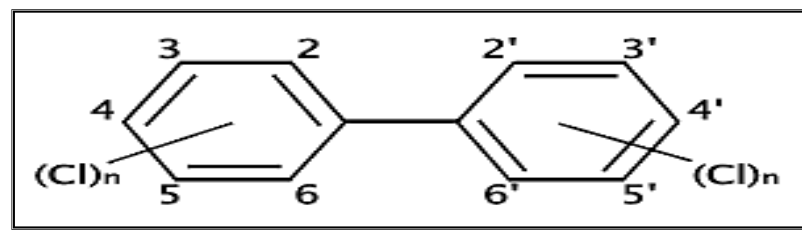

Fig.(3): Polychlorinated Biphenyls (PCBs) structure [16].

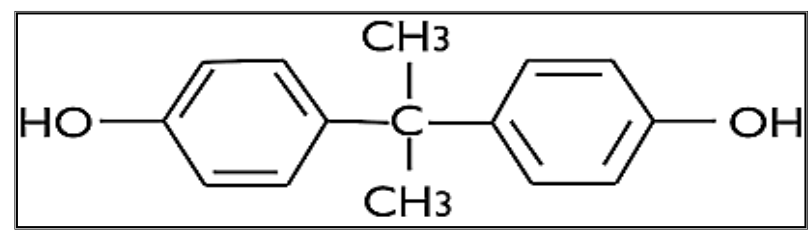

Fig.(4): Bisphenol-A (BPA) structure [17].

\section{Materials and methods}

The present study comprised of 75 individual (40 Female and 35 Male) no symptoms of thyroid disease or any endocrine disease and nonsmoker as well as nonpregnant women. The studied group was divided into three subgroups [ Al-Jadria group (control group) (25), Al-karradah group (25) Abo-Gharib (25)] aged between 15-65 years. blood samples were collected from individual 
in three hospitals, 1) Abdul Majeed private hospital 2) Abu Ghraib General Hospital 3) Jadria Health Center. samples were hospitalized at laboratories in the Abdul Majeed private hospital. the samples were collected from October 2016 to February 2017. blood samples were collected $(5 \mathrm{ml})$ and centrifuged at [4000 rpm] for $10 \mathrm{~min}$ after clotting, to separate the serum from the cells for determination human serum polychlorinated biphenyls (PCBs) and bisphenol-A (BPA) levels. the resultant serum was separated and stored at $[-20]{ }^{\circ} \mathrm{C}$ until time of analyses. human serum thyroxine (T4), Thyrotropin (TSH) and triiodothyronine (T3) were measured using (ELISA) an enzymelinked- immune-sorbent assay kit (Sandwich) technologies for individual in three hospitals using commercially available kits T3, T4, and TSH (Human, Germany).

\section{Measurement of human serum Bisphenol-A Sample Preparation [18]}

Bisphenol-A 0.01gm was dissolved in 200 $\mathrm{mL}$ of acetonitrile. Human serum and $50 \mathrm{ppm}$ bisphenol-A was utilized by high performances liquid chromatography (HPLC) also UV detector, the analytical conditions of the HPLC system were as follows:

Table (1)

Separation Conditions of HPLC.

\begin{tabular}{|c|c|}
\hline Column: & C $_{\mathbf{1 8}}$ ODS \\
\hline \hline Flow Rate: & $1 \mathrm{ml} / \mathrm{min}$ \\
\hline Injection details: & $50 \mu \mathrm{L}$ \\
\hline Mobile phase A: & Methanol \\
\hline Mobile phase B: & Water \\
\hline $\begin{array}{c}\text { UV detector } \\
\text { wavelength: }\end{array}$ & $280 \mathrm{~nm}$ \\
\hline
\end{tabular}

\section{Measurement of human serum}

\section{Polychlorinated biphenyls}

\section{Sample Preparation [19]}

Polychlorinated biphenyls $10 \mathrm{mg} / \mathrm{L}$ were dissolved in $200 \mathrm{~mL}$ of hexane. Human serum of Polychlorinated biphenyls was measured by gas chromatography (GC) with electron capture detector, these solutions were stored at $4^{\circ} \mathrm{C}$ in the absence of light, and the analytical conditions of PCBs were as follows:
Table (2)

The analytical conditions of PCBs.

\begin{tabular}{|c|c|}
\hline \multicolumn{1}{|c||}{ Parameter } & Conditions of GC \\
\hline \hline $\begin{array}{c}\text { Column Oven } \\
\text { (SE-30) }\end{array}$ & $\begin{array}{c}110{ }^{\circ} \mathrm{C}-230\left(3{ }^{\circ} \mathrm{C}\right. \\
\text { /MIN) }\end{array}$ \\
\hline \hline Detector & $\begin{array}{c}\text { Electron Capture } \\
\text { Detector }\end{array}$ \\
\hline \hline Injection Volume & $1 \mu \mathrm{l}$ \\
\hline \hline Pressure & $100 \mathrm{KPa}$ \\
\hline \hline $\begin{array}{c}\text { Temperature } \\
\text { Detector }\end{array}$ & $320{ }^{\circ} \mathrm{C}$ \\
\hline \hline Temperature injector & $280{ }^{\circ} \mathrm{C}$ \\
\hline \hline Carrier Gas & 2.6 ml/min He \\
\hline \hline $\begin{array}{c}\text { Oven program } \\
\text { (Temperature) }\end{array}$ & $\begin{array}{c}60{ }^{\circ} \mathrm{C} \text { for one minute, } \\
\text { also } 20{ }^{\circ} \mathrm{C} / \mathrm{minute} \text { to } \\
\text { minute to } 290{ }^{\circ} \mathrm{C} \\
(3 \text { minute) }\end{array}$ \\
\hline
\end{tabular}

\section{Procedure}

Serum samples $(1 \mathrm{ml})$ for the three groups were denatured with $1 \mathrm{~mL}$ of Methanol. The objective mixes of it were extricated twice with $500 \mu \mathrm{L}$ of $\mathrm{n}$-hexane, in the wake of including the surrogates; the concentrates were consolidated and washed with extremely ultrapure water. The dissolvable of it evaporated buildup was broken down in 3 $\mathrm{mL}$ of $\mathrm{n}$-hexane, went through a glass columns packed, and appears chart on the device [20].

\section{Statistical analysis}

Statistical analysis of data was performed using SAS (Statistical Analysis Systemversion 9.1). One-way ANOVA also Least significances difference (LSD) were performed to survey significances differences among mean. $P$ value $<0.05$ was considered factually significant.

\section{Results and Discussion}

Results were revealed that comparison of persistent organic pollutants in pollutants areas (Al-karadah, Abo-Gharib) and controls (Al-Jadria group) showed that the PCBs and BPA levels of AL-Karradah group were higher than the control group $\mathrm{PCBs}(0.00 \mu \mathrm{g} / \mathrm{L}$ vs. controls $0.00 \mu \mathrm{g} / \mathrm{L}, P<0.0001)$. Respectively; BPA $\quad(28.44 \pm 2.59 \quad \mu \mathrm{g} / \mathrm{L} \quad$ vs. controls $14.82 \pm 1.40 \mu \mathrm{g} / \mathrm{L}, \mathrm{P}<0.0001)$ also PCBs and BPA levels of the Abo.Gharib group was higher PCBs $(0.54 \pm 0.47 \mu \mathrm{g} / \mathrm{L}$ vs. 0.00 
$\mu \mathrm{g} / \mathrm{L}, \quad P<0.0001)$. Respectively: BPA $(28.24 \pm 0.87 \mu \mathrm{g} / \mathrm{L} \quad$ vs. $14.82 \pm 1.40 \mu \mathrm{g} / \mathrm{L}$, $P<0.0001)$.

Table (3)

Mean values, standard error, (mean \pm standard error), maximum, minimum and standard deviation of PCBs and BPA levels in the human serum from three different hospitals in Baghdad.

\begin{tabular}{|c|c|c|}
\hline Region & $\begin{array}{c}\text { Bisphenol- } \\
\mathrm{A}(\mu \mathrm{g} / \mathrm{L})\end{array}$ & $\operatorname{PCBs}(\mu \mathrm{g} / \mathrm{L})$ \\
\hline $\begin{array}{c}\text { Al-Karadah } \\
\text { Min-Max } \\
\text { STD }\end{array}$ & $\begin{array}{c}28.44 \pm 2.59 \mathrm{a} \\
(14.1-35.20) \\
6.86\end{array}$ & 0.00 \\
\hline $\begin{array}{c}\text { Abo.Gharib } \\
\text { Min-Max } \\
\text { STD } \\
\end{array}$ & $\begin{array}{c}28.24 \pm 0.87 \mathrm{a} \\
(24.50-31.30) \\
2.32 \\
\end{array}$ & $\begin{array}{c}0.54 \pm 0.47 \\
(0.06-1.50) \\
0.82 \\
\end{array}$ \\
\hline $\begin{array}{c}\text { Al-Jadriah } \\
\text { (Control) } \\
\text { Min-Max } \\
\text { STD } \\
\end{array}$ & $\begin{array}{c}14.82 \pm 1.40 b \\
(10.40-20.00) \\
3.71\end{array}$ & 0.00 \\
\hline LSD & 5.2827 & 0.9557 \\
\hline $\mathrm{P}$ & $<00.0001$ & $<0.0001$ \\
\hline
\end{tabular}

a,b: The difference letters in the same column means a significant difference in parameters between groups.

PCBs: Polychlorinated Biphenyls/BPA: BisphenolA

LSD: Least significant differences/STD: standard deviation.

Table (4) shows the means, standard deviation, maximum and minimum of thyroxine (T4), Thyrotropin (TSH) and triiodothyronine (T3) for the three studied groups. comparison of thyroid hormones in pollutants areas (Al-karadah, Abo-Gharib) and controls as shown that T3 and TSH levels were not significantly differences between both groups AL-Karradah and AL-Jadria control; T3 (1.14 $\pm 0.08 \mathrm{ng} / \mathrm{ml}$ vs. control: $1.13 \pm 0.05$ $\mathrm{ng} / \mathrm{mL}, P=0.45)$ respectively.; TSH $(2.22 \pm 0.31$ mIU/l vs. control: $1.99 \pm 0.24 \mathrm{mIU} / \mathrm{l}, P=0.44$ ) also shown that the T3 and TSH levels were not significantly differences between both groups Abo.Gharib and AL-Jadria controls:T3 $(1.29 \pm 0.09 \mathrm{ng} / \mathrm{ml}$ vs. control: $1.13 \pm 0.05$ ng/mL, $\quad P=0.445$. respectively; TSH (2.07 $\pm 0.27 \mathrm{mIU} / \mathrm{l}$ vs. control: $1.99 \pm 0.24$ $\mathrm{mIU} / \mathrm{l}, P=0.44)$.
Comparison of thyroid hormones in pollutants areas (Al-karadah, Abo-Gharib) and controls as for T4 Levels were significant differences $(p<0.05)$, between both groups AL-Karradah and AL-Jadria controls; T4 $(9.15 \pm 0.38 \mathrm{ng} / \mathrm{ml}$ vs. control: $8.45 \pm 0.39$ $\mathrm{ng} / \mathrm{mL}, P=0.047)$.The results also showed that the T4 levels were significant differences ( $p<0.05$ ), between both groups Abo.Gharib and AL-Jadria controls: T4 $(9.43 \pm 0.38 \mathrm{ng} / \mathrm{ml}$ vs. control: $8.45 \pm 0.39 \mathrm{ng} / \mathrm{mL}, P=0.047)$.

\section{Table (4)}

Mean values, standard error, (mean standard error), maximum, minimum and standard deviation T3, T4 and TSH levels in the human serum from three different hospitals in Baghdad.

\begin{tabular}{|c||c||c||c||}
\hline Region & T3(ng/ml) & T4(ng/ml) & $\begin{array}{c}\text { TSH } \\
(\mathbf{m I U} / \mathbf{l})\end{array}$ \\
\hline \begin{tabular}{c||c||} 
Al- \\
Karadah \\
Min-Max \\
STD
\end{tabular} & $\begin{array}{c}1.14 \pm 0.08 \\
(0.87-2.65) \\
0.37\end{array}$ & $\begin{array}{c}9.15 \pm 0.38 \mathrm{a} \\
(5.09-12.42) \\
1.88\end{array}$ & $\begin{array}{c}2.22 \pm 0.31 \\
(0.38-5.54) \\
1.52\end{array}$ \\
\hline $\begin{array}{c}\text { Abo- } \\
\text { Gharib }\end{array}$ & $\begin{array}{c}1.29 \pm 0.09 \\
(0.93-2.71) \\
\text { Min-Max } \\
\text { STD }\end{array}$ & $\begin{array}{c}9.43 \pm 0.38 \mathrm{a} \\
(5.57-13.51) \\
1.90\end{array}$ & $\begin{array}{c}2.07 \pm 0.27 \\
0.40-6.09) \\
1.32\end{array}$ \\
\hline $\begin{array}{c}\text { Al-Jadria } \\
\text { (Control) } \\
\text { Min-Max }\end{array}$ & $\begin{array}{c}1.13 \pm 0.05 \\
(0.94-2.04) \\
\text { STD }\end{array}$ & $\begin{array}{c}0.22 \\
(4.86-11.21) \\
1.87\end{array}$ & $\begin{array}{c}(0.45-4.05) \\
1.15\end{array}$ \\
\hline \hline LSD & 0.1985 & 0.9629 & 0.7539 \\
\hline \hline P & 0.45 & 0.047 & 0.44 \\
\hline \hline
\end{tabular}

a,b: The difference letters in the same column means a significant difference in parameters between groups.

T3: Triiodothyronine/ T4: Thyroxine/ TSH: Thyrotropin 
Table (5)

Correlation coefficient between Bisphenol-A and T3, T4 and TSH parameters in Al-karradah.

\begin{tabular}{|c|c|c|c|c|c|}
\hline \multicolumn{2}{|c|}{ Al-karradah } & $\begin{array}{c}\text { Bisphenol-A } \\
(\mu \mathrm{g} / \mathrm{L})\end{array}$ & \begin{tabular}{|} 
Triiodothyronin \\
e $(\mathrm{ng} / \mathrm{ml})$
\end{tabular} & $\begin{array}{l}\text { Thyroxine } \\
(\mu \mathrm{g} / \mathrm{dl})\end{array}$ & $\begin{array}{c}\text { Thyrotropin } \\
\text { (mIU/l) }\end{array}$ \\
\hline \multirow{2}{*}{ Bisphenol-A } & Pearson Correlation & & $-.016-$ & $-.519-$ & .386 \\
\hline & $\mathrm{P}$ & & .976 & .291 & .450 \\
\hline
\end{tabular}

Table (6)

Correlation coefficient between Bisphenol-A and T3, T4 and TSH parameters in Abo-Gharib.

\begin{tabular}{|c|c|c|c|c|c|}
\hline \multicolumn{2}{|c|}{ Abo-Gharib } & $\begin{array}{c}\text { Bisphenol-A } \\
(\mu \mathrm{g} / \mathrm{L})\end{array}$ & \begin{tabular}{|} 
Triiodothyronin \\
e $(\mathrm{ng} / \mathrm{ml})$
\end{tabular} & $\begin{array}{c}\text { Thyroxine } \\
(\mu \mathrm{g} / \mathrm{dl})\end{array}$ & $\begin{array}{c}\text { Thyrotropin } \\
\text { (mIU/l) }\end{array}$ \\
\hline \multirow{2}{*}{ Bisphenol-A } & Pearson Correlation & & $-.741-$ & $-.024-$ & .023 \\
\hline & $\mathrm{P}$ & & .092 & .964 & .966 \\
\hline
\end{tabular}

Table (7)

Correlation coefficient between Bisphenol-A and T3, T4 and TSH parameters in Al-Jadriah.

\begin{tabular}{|c|c|c|c|c|c|}
\hline \multicolumn{2}{|c|}{ Al-Jadriah } & \begin{tabular}{|c|} 
Bisphenol-A \\
$(\mu \mathrm{g} / \mathrm{L})$
\end{tabular} & $\begin{array}{c}\text { Triiodothyronin } \\
\text { e }(\mathrm{ng} / \mathrm{ml})\end{array}$ & $\begin{array}{l}\text { Thyroxine } \\
(\mu \mathrm{g} / \mathrm{dl})\end{array}$ & $\begin{array}{c}\text { Thyrotropin } \\
\text { (mIU/l) }\end{array}$ \\
\hline \multirow{2}{*}{ Bisphenol-A } & Pearson Correlation & & ב.597 & .056 & $\begin{array}{l}-.527- \\
\end{array}$ \\
\hline & $\mathrm{P}$ & & .210 & .916 & .283 \\
\hline
\end{tabular}

Bisphenol -A is broadly utilized as a crude material in produce, bringing about its pervasive dispersion in characteristic environment toxins, including the watery condition. Be that as it may, the impact of BPA on the thyroid endocrine is to a great extent obscure, bio concentration of BPA and entire body thyroid hormones, thyrotropin identified with the hypothalamic-pituitary-thyroid (HPT) were inspected. The impacts of bisphenol-A on human wellbeing, exhibited that formative presentation to BPA caused poisoning. The pollutants of BPA and its analogs have increased incredible concern due to their possibly adverse wellbeing impacts in this investigation, we assessed the system of thyroid endocrine disruption caused by BPA. The outcomes showed that BPA fundamentally changed entire body $\mathrm{TH}$ and TSH focuses proposing the thyroid endocrine disturbing effects of BPA, so the emergence of a large number of bisphenol-A pollutants found many pollute in the areas of Karradah and Abo- Gharib compared with the control Al-Jadria region [21]. In addition, BPA can alter thyroid-specific gene expression and functions [22]. Concentrations of PCBs a compound detected in the human serum samples are summarized only in abo-Gharib region and shows chromatography obtained by gas chromatography-ECD for human, PCBs components were successfully separated with good resolution.

The analytical conditions of PCBs concentrations detected in the human serum samples are summarized only in abo-Gharib region compared with control al-Jadria region.Within PCBs risk survey when searching further for additional signs of hyperthyroidism e.g. increased T4 plus increased T3 among the subjects causes with very low TSH and very high PCBs level, So, identified a total level, we called these cases "high PCBs related subclinical hyperthyroidism" since they showed fundamental laboratory signs of hyperthyroidism (very low TSH and very high T4 and T3) thus, from our findings it may be concluded that TSH level tends to decrease with increasing levels of PCBs which is contrasting to several findings of increased TSH level by others, the important role of individual susceptibility in the development of adverse health effects related To PCBs. Previously study identified cases with very high PCBs and at the same time low TSH and 
high T4, this further possibly results in increased input of $\mathrm{T} 4$ to the cells and increased intracellular $\mathrm{T} 4$ to $\mathrm{T} 3$ conversion including pituitary cells which contributes to a final decrease of TSH [23-25].

\section{Conclusions}

Through our research, we found that the presence of Persistent Organic Pollutants in the area of al-Karadah and Abo.Gharib resulting from explosions and terrorist operations also environmental pollution in high quantities. The relationship among POPs as well as thyroid hormones have been studied. General al-karadah and Abo.Gharib populace observed inverse associations between the sera bisphenol-A, and T3 and T4 levels. The observed relationship between POPs toward thyroid hormones disruption. On the other hand an emergence of a large number of bisphenol-A and polychlorinated biphenyls pollutants found in most residents of alKarradah and abo-Gharib areas compared to al-Jadria region (control group) as the lowest percentage of pollution. The effect of war (terrorist operation) on the environment in Iraq results of pollution of persistent organic pollutants showing that expanded POPS in the blood are probably going to diminish thyroid hormone creation. Environmental factors have been conjectured to be persuasive in thyroid hormone generation. This study show an additional sign that persistent organic pollutants are related to thyroid hormones.

\section{References}

[1] Hossam A. Z., Adnan M. A., and Hisham N. W., Baseline Concentration of Heavy Metals in Fish Collected from Gaza. Turkish Journal of Fisheries and Aquatic Sciences, 17, 101-109, 2017.

[2] Isaac E., E., and Sylvester S., O., Assessment of the concentrations of some heavy metals and their effects on the macroinvertebrate composition in Igun southwestern Nigeria, using reference site approach. Journal of Entomology and Zoology Studies, 5(1), 452-458, 2017.

[3] Srishty S., Jerald L. S., and Benoit V. A., Effects of polychlorinated biphenyls (PCBs) and their hydroxylated metabolites (OH-PCBs) on Arabidopsis thaliana
Environmental Science \& Technology, 128, 2017.

[4] Yousif E., Jawad A., Hammed A., Adi H, Hasan A., Al-Qaisi Z., Redwan A., Study the Level and the Fluctuation of Induced Nitric Oxide Synthase in Iraqi Patients with Hypertension, Journal of Progressive Research in Chemistry, 3(4), 189-193, 2017.

[5] Faheem M., Jahan N., and Lone K. P., Histopathological effects of Bisphenol-A on liver, kidneys and gills of Indian major carp, catla (Hamilton 1822). The Journal of Animal \& Plant Sciences, 26(2), 514-522, 2016.

[6] Shelby F. a., Tricia M. a., Sarah T. b., Elizabeth W., Bisphenol- A exposure, effects and policy: A wildlife perspective. Journal of Environmental Management, 104, 19-34, 2012.

[7] Moutaz A. A., Lamyaa A. A., and Adnan H. A., The effect of Kirkuk Oil Refinery on Air pollution of Kirkuk City-Iraq, Iraqi journal of science, 8-18, 2012.

[8] Kyla M. W., Yan-ping L., Philip H. K., and Birgit P., Association of Polybrominated Diphenyl Ethers and Polychlorinated Biphenyls with Hyperthyroidism in Domestic Felines, Sentinels for Thyroid Hormone Disruption. Walter et al. BMC Veterinary Research, 13(120), 1-12, 2017.

[9] Moriyama K., Tagami T., Akamizu T., Usui T., Saijo M., Kanamoto N., Hataya Y., Shimatsu A., Kuzuya H., and Nakao K., "Thyroid Hormone action is disrupted by bisphenol A as an antagonist. Journal of Clinical Endocrinology and Metabolism", 87 (11), 5185-5190, 2002.

[10] Catherine V., Severine C., Veronique G.T., Nicole H.P., Sylvie P., Beatrice R., PierreL. T., Marlene L., Maternal and Fetal Exposure to Bisphenol- A Is Associated with Alterations of Thyroid Function in Pregnant Ewes and Their Newborn Lambs. Endocrinology, 154(1), 521-528, 2013.

[11] Meeker JD., Calafat AM., Hauser R., Urinary bisphenol- A concentrations in relation to serum thyroid and reproductive hormone levels in men from an infertility clinic. Environmental Science and Technology, 44(4), 1458-1463, 2010. 
[12] Laor C., Wichai A., and Boonsong O., the Association of Serum Bisphenol -A with Thyroid Autoimmunity. International Journal of Environmental Research and Public Health. 13(1153), 1-7, 2016.

[13] Gihan G. M., Amal A.M. A., Impact of prenatal and postnatal Exposure to bisphenol- A on female rats in a two generational study: Genotoxic andimmuno his to chemical implications. Toxicology Reports, 3, 685-695, 2016.

[14] Mauro C., Cristiano F., Germana S., Carlo B., Fiorenzo M., and Lucio T., Toxic Emissions from a Military Test Site in the Territory of Sardinia, Italy, International Journal of Environmental Research and Public Health. 10, 1631-1646, 2013.

[15] Boelaert K., and Franklyn J. A., Thyroid hormone in health and disease. Journal Endocrinal, 187(1), 1-15, 2005.

[16] Xueyun Z., Kevin T. D., Noor A. A., Yuxuan Z., Francesca B. S., Keqi T., Richard D. S., Erin S. B., Utilizing ion mobility spectrometry and mass spectrometry for the analysis of polycyclic aromatic hydrocarbons, polychlorinated biphenyls, polybrominated dipheny ethers and their metabolites, Analytica Chimica Acta, 1-21, 2018.

[17] Yin L., Lalith P., Laurel A. C., Katherine A. B., Ramsey J. T., Katherine E. P.,René H. R. B., Christina T. T., and Kenneth S. K., Differential in Vitro Biological Action, Coregulator Interactions, and Molecular Dynamic Analysis of Bisphenol A (BPA), BPAF, and BPS Ligand-ERa Complexes, Environmental Health Perspectives. 126(1), 1-16, 2018.

[18] Derek H., Separation of a Mixture of PCBs Using an Accurse C18 HPLC Column. Thermo Fisher Scientific, 1-3, 2012.

[19] Lydon D. A., Barry J. M., Paul D. M., and Oliver A. H. J., A New Method for the Fast Analysis of Trihalomethanes in Tap and Recycled Waters Using Headspace Gas Chromatography with Micro-Electron Capture Detection. International Journal of Environmental Research and Public Health, 14(527), 1-9, 2017.

[20] Akifumi E., Takeshi E., Norimichi S., Miho O., and Chisato M., Development of
Simple Analytical Methods of Polychlorinated Biphenyls in Human Serum by Gas Chromatography Negative Ion Chemical Ionization Quadrupole Mass Spectrometry. Original Research Paper ,1-4, 2016.

[21] Dan-hua Z., En-xiang Z., Zhu-lin Y., Waterborne exposure to BPS Cause thyroid endocrine disruption in zebrafish larvae. PLOS ONE,12(5) ,1-17,2017.

[22] Virág S., Tamás L. H., István T., Tibor B., László V. F., Dávid S. K., Gergely J., Annamária K., Frederick N. and Attila Z., Bisphenol A influences oestrogen and thyroid hormone regulated thyroid hormone receptor expression in rat cerebellar cell culture. Acta Veterinaria Hungarica, 64(4), 497-513, 2016.

[23] Pavel L., Anton K., Mária T., Tomá T. and Iwar K., What We Learned from the Study of Exposed Population to PCBs and Pesticides. The Open Environmental Pollution \& Toxicology Journal, 1,54-65, 2009.

[24] Hassan F., Mohammed G., El-Hiti G., Alshanon A., Yousif E., Journal of Unexplored Medical Data,. Cytotoxic effects of tamoxifen in breast cancer cells, 3, 1-9, 2018.

[25] Jawad A., Ibrahim A., Hammed A., AlQaisi Z., Redwan A, Yousif E., 4-Hydroxy2-nonenal Statues in Hypertension Patients, Preprints, doi:10.20944/preprints201703.0037.v1, 2017. 